\title{
Building Brand Equity Through Corporate Societal Marketing
}

\author{
Steve Hoeffler and Kevin Lane Keller
}

\begin{abstract}
Marketers have shown increasing interest in the use of corporate societal marketing (CSM) programs. In this article, the authors describe six means by which CSM programs can build brand equity: (1) building brand awareness, (2) enhancing brand image, (3) establishing brand credibility, (4) evoking brand feelings, (5) creating a sense of brand community, and (6) eliciting brand engagement. The authors also address three key questions revolving around how CSM programs have their effects, which cause the firm should choose, and how CSM programs should be branded. The authors offer a series of research propositions throughout and conclude by outlining a set of potential future research directions.
\end{abstract}

$\mathbf{T}$ The use of corporate societal marketing (CSM) appears to be on the rise in accordance with the increasing recognition of the vast potential of CSM programs (e.g., Drumwright 1996; File and Prince 1998; Varadarajan and Menon 1988). Corporate societal marketing is defined to "encompass marketing initiatives that have at least one non-economic objective related to social welfare and use the resources of the company and/or one of its partners" (Drumwright and Murphy 2001, p. 164). One factor driving this growth in CSM is the realization that consumers' perceptions of a company as a whole and its role in society can significantly affect a brand's strength and equity. For example, the 1999 Cone/Roper Cause-Related Trends Report revealed that among U.S. residents (1) $80 \%$ have a more positive image of companies that support a cause that they care about, (2) nearly two-thirds report that they would be likely to switch brands to one associated with a good cause, and (3) almost three-quarters approve of cause programs as a business practice.

Corporate societal marketing has been used to satisfy multiple objectives. Goals for companies that implement successful CSM programs include "creat(ing) a differential advantage through an enhanced corporate image with consumers" (Lichtenstein, Drumwright, and Braig 2000, p. 4) and "differentiat(ing) themselves from the competition by building an emotional, even spiritual, bond with consumers" (Meyer 1999, p. 29). Other benefits exist too. For example, the Muscular Dystrophy Association's (2001) Web site lists the following benefits of affiliation for corporate partners: "It's good business to do business with MDA. The Association's programs can (1) Enhance your company's public image; (2) Boost employee morale; (3) Draw attention to a product or service; and (4) Contribute to an increase in sales." Moreover, CSM programs may provide a reservoir of goodwill that will help deflect criticism and overcome negative publicity from an unexpected event or tragedy (Dawar and Pillutla 2000).

STEVE HoEFFLER is an assistant professor, Kenan-Flagler School of Business, University of North Carolina. Kevin LANE KELLER is the E.B. Osborn Professor of Marketing, Amos Tuck School of Business, Dartmouth College.
Although the potential benefits of CSM programs are vast, we focus on the specific benefits of CSM programs with regard to the shaping of brand equity. Corporate societal marketing programs are poised to play a more important role in brand marketing. For that to happen, however, marketers must understand what to expect and what not to expect from CSM programs. Accordingly, the goal of this article is to examine some critical decisions associated with establishing an effective, brand-building CSM program. We outline six ways that CSM programs can affect brand equity. With that broad background, we next turn to three crucial CSM issues. First, we consider in greater detail the factors that determine the manner in which CSM programs affect brand equity. Second, we examine the choice of which cause to support-for example, a cause that has much in common with the current image of the brand versus a cause that could complement and augment what the brand already stands for. Third, we address the branding strategy for the CSM program itself, that is, whether it is more appropriate to link the brand to an existing cause (cobranding, as with American Airlines' official sponsorship of the Susan G. Komen Breast Cancer Foundation), create a new program or cause (self branding, as with McDonald's Ronald McDonald House Charities), or use some combination of the two (joint branding, as with American Express's Charge Against Hunger program in conjunction with the Share Our Strength foundation). The article also develops a series of research propositions and concludes by outlining a set of possible future research directions.

\section{CSM Programs and Brand Equity}

Building a strong brand is the goal of many organizations because of the host of possible benefits that may result. To understand better how to build brand equity, several models and viewpoints of brand building have been put forth (Aaker and Joachimsthaler 2000; Farquhar 1989). Essentially all the theoretical approaches in one way or another interpret branding effects in terms of consumer knowledge about the brand and how that knowledge affects consumer behavior. For example, Keller (1998, 2001) defines customer-based brand equity as the differential effect that brand knowledge has on customer response to marketing activity. The basic 
premise of his model is that the power of a brand lies in what customers have learned, felt, seen, heard, and so forth about the brand as a result of their experiences over time.

In other words, the power of a brand is in what resides in the minds of customers. The challenge for marketers in building a strong brand is ensuring that customers have the right type of experiences with products and services and their accompanying marketing programs so that the desired thoughts, feelings, images, beliefs, perceptions, opinions, and so on become linked to the brand. As we outline subsequently, a well-designed and implemented CSM program could provide many important associations to a brand. In the following sections, we briefly highlight the following six means by which CSM programs can help build brand equity:

1. Building brand awareness,

2. Enhancing brand image,

3. Establishing brand credibility,

4. Evoking brand feelings,

5. Creating a sense of brand community, and

6. Eliciting brand engagement.

\section{Building Brand Awareness}

Formally, brand awareness refers to the customers' ability to recall and recognize the brand. Brand awareness is more than just customers knowing the brand name and having previously seen the brand, perhaps even many times. Brand awareness also involves linking the brand - the brand name, logo, symbol, and so forth-to certain associations in memory. Brand awareness can be distinguished in terms of two key dimensions: Depth of brand awareness refers to how easily customers can recall or recognize the brand; breadth of brand awareness refers to the range of purchase and consumption situations in which the brand comes to mind. Ideally, a brand would have both depth and breadth of brand awareness. Higher depth of brand awareness leads to increased sales if consumers are more likely to think of the brand when the need arises (e.g., Coke when thirsty). Higher breadth of brand awareness leads to increased sales if consumers are more likely to think of the brand across a variety of settings when it could be employed or consumed (e.g., Coke in the morning).

Two important measures of brand awareness are recognition and recall. Brand recognition is the ability of the consumer to confirm prior exposure to the brand, and brand recall is the unaided retrieval of the brand from memory. In many cases, because of the nature of the brand exposure, CSM programs seem to be a means of improving recognition for a brand, but not necessarily recall. Brand recall relies more heavily on creating the appropriate links between the brand and the product category or the consumption or usage situation. As with sponsorship and other indirect forms of brand-building communications, most CSM programs are not geared toward creating these types of links, as they are unable or unwilling to include much product-related information. At the same time, exposure to the brand can literally be repeated and/or prominent as a result of the CSM program, which facilitates brand recognition.
$\mathrm{P}_{1}$ : CSM programs (a) will lead to increases in awareness for a brand and (b) will not lead to enhanced associations related to specific consumption or usage situations.

\section{Enhancing Brand Image}

Brand awareness is an important first step in building brand equity, but it usually is not sufficient. For most customers in most situations, other considerations, such as the meaning or image of the brand, also come into play (Fournier 1998; Zaltman and Higie 1995). Enhancing brand image involves creating brand meaning and what the brand is characterized by and should stand for in the minds of customers. Several types of associations - related broadly to more functional, performance-related considerations or more abstract, imagery-related considerations-may become linked to the brand. In particular, to create brand equity, it is important that the brand have some strong, favorable, and unique brand associations (Keller 1993).

Corporate societal marketing offers several means of creating such favorable brand differentiation. As mentioned previously, most CSM programs do not include much product-related information; therefore, CSM programs would not be expected to have much impact on more functional, performance-related considerations. In contrast, several kinds of more abstract or imagery-related associations would seem to be able to be linked to a brand through CSM. Two such types of associations are (1) user profiles and (2) personality and values.

\section{User Profiles}

One set of brand imagery associations is the type of person who uses the brand. This imagery may result in a profile or mental image by customers of actual users or more aspirational, idealized users. Associations of a typical or idealized brand user may be based on descriptive demographic factors or more abstract psychographic factors. The CSM may enable consumers to develop a positive image of brand users to which they also may aspire, for example, in terms of being kind and generous and doing good things.

$\mathrm{P}_{2}$ : The more prominent user imagery is in the marketing program (e.g., as the focus of an advertising campaign), the more likely it is that the brand image will be enhanced.

\section{Brand Personality}

Brands may also take on personality traits and values, similar to people. Brand personality is often related to the more descriptive user or usage imagery but involves much richer, more contextual information. One often-cited dimension of brand personality is sincerity (e.g., Aaker 1997, 1999). Corporate societal marketing could bolster the sincerity dimension of a brand's personality such that consumers would perceive the people behind the brand as caring and genuine.

As an example of a CSM program that could help enhance brand image and the perceived sincerity of the brand, consider the following:

Liz Claiborne: Women's Work campaign against domestic violence. In 1991, at a time when domestic violence was often a taboo or "hot potato" issue, Liz Claiborne developed its Women's Work campaign against domestic violence. Prior to starting the campaign, the company had conducted research that 
revealed that 96 percent of its customers believed that domestic violence was a problem and 91 percent of those same customers would have a positive opinion of a company that started an awareness campaign about the issue. The major fundraising event is an annual charity shopping day every October at Liz Claiborne stores across the U.S. The company donates 10 percent of sales to local domestic violence organizations. Liz Claiborne also contributes proceeds from the sale of t-shirts, jewelry, and other products related to the campaign. Additionally, the company pays for public service campaigns that appear on television, radio, billboards, and bus shelters and distributes awareness posters, brochures, and mailings. Over the years, Liz Claiborne has also sponsored workshops, surveys, celebrityendorsed awareness campaigns, and other events. (Pringle and Thompson 1999, p. 229)

In the Liz Claiborne example, the brand's promotion of the CSM programs should improve the brand's awareness and image. Awareness is improved from increased customer exposure to the brand name/symbol. Image is improved if consumers appreciate the CSM efforts of Liz Claiborne and think of the brand in a new light (e.g., more caring). Yet there are no positive, concrete associations that are transferred to the Liz Claiborne brand. By concrete associations, we mean associations pertaining to product-related attributes. Instead, it is the abstract associations, focused on the image of Liz Claiborne, that are more likely to be transferred.

These two types of abstract or imagery-related associations can be quite valuable given prior research that has shown the ability of more abstract associations to be relevant in more varied product contexts (Johnson 1984; Park, Milberg, and Lawson 1991). Greater transferability across product settings might also suggest greater transferability from a cause to another entity, as follows:

$\mathrm{P}_{3}$ : Abstract associations are more likely to be transferred from a cause to a brand than concrete associations are.

\section{Establishing Brand Credibility}

In part by virtue of the imagery they create, CSM programs can also generate various types of judgments and feelings from consumers that may also become linked to the brand. For example, customers may form judgments that transcend more specific brand quality concerns to consider broader issues related to the company or organization that makes the product or provides the service associated with the brand (Brown 1998; Brown and Dacin 1997; Menon and Menon 1997; Schumann, Hathcote, and West 1991). Brand credibility refers to the extent to which the brand as a whole is perceived as credible in terms of three dimensions (Keller and Aaker 1992): expertise (e.g., being competent and innovative and being a market leader), trustworthiness (e.g., being dependable and keeping customer interests in mind), and likability (e.g., being fun, interesting, and worth spending time with). More important, CSM could affect all three considerations, as consumers may perceive a firm willing to invest in CSM as caring more about customers and as more dependable, at least in a broad sense, as well as likable for "doing the right things."

If the cause bears some relation to the line of business for the firm or the nature of its products, the firm may seem more well-rounded and thus more expert. For example, a recent campaign by Procter \& Gamble (P\&G) linked two of its brands (Always and Tampax) to women's health issues. Specific associations may have resulted in terms of $P \& G$ as the brand that cares about women's issues. In that sense, CSM could help consumers link $P \& G$ and its specific brands (Always and Tampax) to women's health. Moreover, consumers might transfer some of the positive feelings they have in regard to the importance of women's health issues to their attitude about $P \& G$ as a corporation or to the specific brands. Analogous to the Liz Claiborne example, consumers may believe that $\mathrm{P} \& \mathrm{G}$ is a caring company that supports good causes. Furthermore, true credibility could be enhanced for the $P \& G$ brands if more direct effects are observed.

The expertise of $P \& G$ could be enhanced if consumers perceive synergies between $P \& G$ 's support of health-related research and the firm's ability to develop innovative new products. Of the dimensions mentioned previously, likability or positive "halo" effects are probably the most likely to be transferred from CSM programs. Yet firms should not underestimate the ability of CSM programs to build both trustworthiness and expertise. In general, CSM programs may be especially good at creating credibility because the nonprofit organization may be perceived as unbiased and as a highly credible source. This may affect how firms communicate their involvement with the CSM program.

\section{Evoking Brand Feelings}

In terms of brand feelings (Kahle, Poulos, and Sukhdial 1988), two categories of feelings that are particularly applicable to CSM are (1) social approval and (2) self-respect. In other words, CSM may help consumers justify their selfworth to others or themselves. These two types of feelings are extremely different in terms of how they are created and in their implications, as follows.

\section{Social Approval}

Social approval is when the brand results in consumers having positive feelings about the reactions of others-that is, when consumers believe others look favorably on their appearance, behavior, and so on. This approval may be a result of others' direct acknowledgment of the consumer using the brand or may be less overt and a result of attribution of the product itself to consumers. To the extent that consumers believe that CSM programs create favorable user imagery for the brand, social approval feelings may also emerge. To accentuate these types of feelings, CSM programs may need to provide consumers with external symbols to explicitly "advertise" or signal their affiliation to others-for example, bumper stickers, ribbons, buttons, tshirts, and so on. The importance of linking the brand to CSM partners that enhance social approval is heightened for brands that have difficulty creating these types of feelings. For example, products whose use is not visible are hampered in this respect (Graeff 1996).

\footnotetext{
$\mathrm{P}_{4}$ : Enhanced levels of feelings of social approval will be created when CSM programs provide consumers with external symbols to explicitly advertise or signal their affiliation to others.
} 


\section{Self-Respect}

Self-respect occurs when the brand makes consumers feel better about themselves, for example, when consumers feel a sense of pride, accomplishment, or fulfillment. To accentuate these types of feelings, CSM programs can give people the notion that they are doing the right thing and that they should feel good about themselves for having done so. External symbols in this case may not be as important as the creation of "moments of internal reflection" during which consumers are able to experience these types of feelings. Communications that reinforce the positive outcomes associated with the cause program-and the way consumer involvement contributed to that success-could help trigger these types of experiences. To highlight the consumer contribution, it may be necessary to recommend certain actions or outcomes as targets for consumers (e.g., have consumers donate a certain percentage of their income or a designated amount).

$\mathrm{P}_{5}$ : Enhanced levels of feelings of self-respect will be created when CSM programs provide consumers with moments of internal reflection that reinforce the positive outcomes associated with the cause program and the way their involvement contributed to that success.

As an example of a CSM program that can evoke feelings, consider the following:

British Airways: Change for Good. British Airways partnered with UNICEF and developed a cause marketing campaign called Change for Good, where travelers on British Airways flights are encouraged to donate leftover foreign currency from their travels. Since coins in particular are difficult to exchange at banks and currency exchanges, the program targets this loose change. The scheme is simple: Passengers deposit their surplus currency in envelopes provided by British Airways, which collects the deposits and donates them directly to UNICEF. British Airways advertises its program during an in-flight video, on the backs of seat cards, and with in-flight announcements. The company also developed a television advertisement that featured a child thanking British Airways for its contribution to UNICEF works. Since Change for Good can be directly targeted to passengers and can produce immediate results, it does not require extensive advertising or promotion and therefore is a highly cost-efficient cause marketing campaign. (Pringle and Thompson 1999, p. 132)

Consumers on British Airways flights who donate change (or bills) may immediately feel social approval and selfrespect from the surrounding passengers. If British Airways and UNICEF provided a pin to those contributing, perhaps these feelings may be further enhanced and more positive attitudes developed toward both British Airways and UNICEF.

\section{Creating a Sense of Brand Community}

The judgments and feelings engendered by a CSM program could influence the nature of the relationship consumers have with the brand. For example, brands can take on broader meaning to the customer in terms of a sense of community that CSM programs could affect. Identification with a brand community can reflect an important social phenomenon whereby customers feel a kinship or affiliation with other people who are associated with the brand. These con- nections may involve fellow brand users or customers or, instead, employees or representatives of the company.

According to Kraft Foods chief executive officer and president Robert Eckert, "Consumers are yearning to connect to people and things that will give meaning to their lives" (Stark 1999, p. 8). Muniz and O'Guinn (2000) have defined "brand communities" as specialized, nongeographically bound communities, based on a structured set of social relationships among users of a brand. They note that, similar to other communities, a brand community is marked by (1) a shared consciousness, (2) rituals and traditions, and (3) a sense of moral responsibility. A CSM program with a well-chosen cause can serve as a rallying point for brand users and a means for them to connect to or share experiences with other consumers or employees of the company itself.

One area where communities of like-minded users exist is online. Marketers may be able to tap into the many closeknit online groups that have been created around causerelated issues (e.g., medical concerns such as Alzheimer's disease, cancer, autism, and so forth). In some cases, the brand might even serve as the focal point or ally for these online efforts. As a result of these community-building initiatives, the brand may be perceived in a more positive light. Involvement in a brand community inherently involves active engagement with the brand. Yet consumers can be engaged with a brand without being members of a brand community.

\section{Eliciting Brand Engagement}

Perhaps the strongest affirmation of brand loyalty is when customers are willing to invest time, energy, money, or other resources into the brand beyond those expended during purchase or consumption of the brand. For example, customers may choose to join a club centered on a brand, receive updates and exchange correspondence with other brand users or formal or informal representatives of the brand itself, visit brand-related Web sites, participate in chat rooms, and so on. Participating in a cause-related activity as part of a CSM program for a brand is certainly one means of eliciting active engagement. As part of any of these activities, customers themselves may become brand evangelists and ambassadors and help communicate about the brand and strengthen the brand ties of others. A CSM program of "strategic volunteerism," whereby corporate personnel volunteer their time to help administer the nonprofit program, could be used to engage consumers actively with both the cause and the brand. In the following Habitat for Humanity example, Whirlpool reaps the benefits of volunteers being exposed to its product while they are engaged with the cause.

Whirlpool Corp.: Habitat for Humanity. The people who make and sell Whirlpool appliances have become the first cornerstone contributors in Habitat for Humanity's "More Than Houses: Rebuilding Our Communities" campaign. Whirlpool Corp. has pledged to provide new stoves and refrigerators for every Habitat house built in the United States and Canada through the end of the campaign. Representing \$25 million in product value, it is the largest one-time commitment made by a corporate partner in Habitat history. (Habitat for Humanity International 2001) 


\section{Summary}

Corporate societal marketing programs can help build brand equity in multiple ways, as outlined previously. To illustrate the range of effects potentially created by CSM programs, consider BMW's "The Drive for the Cure" test drive program, which donates $\$ 1$ for every test mile driven to the Susan G. Komen Breast Cancer Foundation to fund research. Through this program, BMW is able to target women, who have not traditionally been a key market segment for BMW (Pringle and Thompson 1999), increasing their brand awareness. In terms of brand image, the experience of driving the car can affect participants' performancerelated associations. Moreover, the program can influence the types of imagery attached to BMW with regard to the perceived user profiles and brand personality of BMW among women. As Pringle and Thompson (1999, p. 127) note, "Harder to quantify, but equally important, is the 'softer' image that will have been added to the BMW brand personality and the link in people's minds between what might have previously been seen as a hard or masculine image and something as personal as breast cancer with its more relevant appeal to women." One aspect of the imagery-related effects is the potential positive residual impact for consumers who become aware of the program without ever participating in a test drive. Finally, the Drive for the Cure program could improve credibility as well as social approval and/or self-respect. In part because of these brand equity effects, BMW reportedly attributed 400 new sales directly to the CSM program (Pringle and Thompson 1999).

With these various means by which CSM could affect brand equity as a backdrop, we consider issues regarding (1) how CSM programs have their effects, (2) which cause to choose, and (3) how CSM programs should be branded.

\section{How Do CSM Programs Have Their Effects?}

The prior section outlined six effects CSM programs may have on brand equity. In this section, we consider the factors that affect whether CSM programs realize that potential-in other words, the means by which CSM programs have their effects. The recognition and awareness a brand receives from a CSM program, as noted previously, is largely a function of the amount and nature of brand exposure involved. However, in terms of higher-order effects, the ability of a CSM program to create a sense of community and elicit brand engagement will be a function of the kind of associations, judgments, and feelings engendered by the program. Accordingly, in this section, we consider the following two main types of associations and responses that can be transferred from the cause: (1) specific performance and imagery associations linked to the cause and (2) overall judgments of and feelings engendered by the cause.

The two basic questions involving transferring meaning or responses from a cause are (1) What do consumers know about the cause? and (2) Does any of this knowledge affect what they think about the brand when it becomes linked or associated in some fashion with the cause? We propose a three-factor hierarchy to describe the nature of the transfer process that occurs as a result of a CSM program. The basic assumption is that the cause, similar to the brand itself, can be thought of in terms of what exists in the minds of consumers - that is, in terms of cause-related thoughts, feelings, images, experiences, perceptions, beliefs, opinions, and so forth. The question then becomes how these various types of associations and responses affect the consumer mind-set or knowledge for the brand itself.

Specifically, three factors are particularly important in predicting the extent of leverage that might result from linking the brand to a cause through a CSM program in some manner:

1. Awareness and knowledge of the cause: If consumers have no familiarity with or knowledge of the cause, then there is nothing that can be transferred. Ideally, consumers would be aware of the cause; hold some strong, favorable, and unique associations toward the cause; and have positive judgments and feelings about the cause.

2. Relevance and meaningfulness of the cause's knowledge: Given that the cause has some potentially positive associations, judgments, and/or feelings, to what extent is this knowledge deemed relevant and meaningful for the brand? The meaningfulness of this knowledge may vary depending on the brand and product context. For consumers, some associations, judgments, or feelings may seem relevant to and valuable for the brand, whereas other knowledge may seem to have little connection.

3. Transferability of the cause's knowledge: Assuming that some potentially useful and meaningful associations, judgments, or feelings exist for the cause and could be transferred to the brand, to what extent will this knowledge become linked to brand? Thus, a key issue is the extent to which associations will become strong, favorable, and unique and judgments and feelings will be considered positive in the context of the brand.

Each of these factors is built on the successful completion of the preceding factor. For example, there must be awareness before relevance and meaningfulness can be built. According to this model, to increase the brand-building impact of a CSM program, marketers should maximize the contribution of each of the three factors in the CSM brand leverage model. In the remainder of this section, we consider issues affecting these three factors.

\section{Awareness and Knowledge of the Cause}

This factor involves the potential pool of associations, responses, and so forth that may be elicited by the CSM program by virtue of the choice of the cause. When considering the potential pool of associations that may be transferred through a CSM program, firms need to evaluate the existing associations attached to a particular cause (e.g., breast cancer research) as well as nonprofit organizations that might be affiliated with the cause (e.g., Susan G. Komen Breast Cancer Foundation) if they are partnering with an existing nonprofit. When firms try to transfer specific associations from a cause, it is important to examine the strength and favorableness of the current associations held by consumers. A more memorable cause may make it easier to link the cause to a brand.

In general, the favorability of the associations coupled with a cause will be based on the perceived benefits associated with the cause and, as a result, are inextricably driven by the links between consumers' personal values and the 
values espoused by the cause. Critically analyzing the perceived favorability of a cause may be especially important for a firm that is creating a self-branded cause, as is discussed further subsequently.

\section{Relevance and Meaningfulness of the Cause}

Theoretically, any association may be inferred from a cause to the brand. In general, judgments or feelings may be more likely to transfer from the cause than are more specific associations. Many specific associations are likely to be perceived as irrelevant or too strongly linked to the original cause to transfer to the brand. That is, the process by which associations from a cause affect brand knowledge will depend largely on the strength of the linkage or connection in consumers' minds between the brand and the cause.

$\mathrm{P}_{6}$ : The more consumers perceive fit or similarity of the cause to the brand, the more likely consumers will infer similar associations to the brand.

The relevance of a cause will certainly vary by consumers. One possible way to improve relevance is by emphasizing local aspects of the cause. Consumers may be more likely to notice the impact of a cause if they can see the impact in their local community. Thus, relevance should be enhanced when consumers believe that the nonprofit organization is not only doing good things in general but also doing good things in "my community." Community may be defined by any connection that ties people together. In general, relevance will be enhanced if the CSM program is believed to have a more personal impact on the target consumer. For national brands, this realization may entail more grassroots CSM activity at the local level.

$\mathrm{P}_{7}$ : Consumers will have greater levels of relevance for a brand when the CSM program partner has a higher perceived personal impact.

\section{Transferability from the Cause}

One way to enhance the level of transfer from a cause is through the rewards given to those who participate in the cause. The more ways consumers perceive the brand and the nonprofit organization as linked together, the more opportunities there are for transfer of associations from the nonprofit to the brand. In addition, rewards that happen on a recurring basis should be more likely to improve the consistency of consumers' contact with the cause. Last, the favorability of the associations linked to a cause may be affected by the quality of the reward materials/items. For example, imagine a scenario in which a nonprofit organization sends out high-quality plaques to contributors. If the plaque identifies the firm, the nonprofit, and the cause, then these associations will be reinforced. Furthermore, if the plaque is put up in either the home or office of the contributor, every time the contributors glance at the plaque they will be reminded of their involvement and the relationship between the firm and the cause.

$\mathrm{P}_{8}$ : The more opportunities consumers have to experience connections between the cause and the brand, the stronger will be the associations between the cause and the brand.

Finally, "secondary associations" derived from a CSM program may be most likely to affect evaluations of a new product, in general, when consumers lack either the motivation or the ability to judge more product-related concerns. In other words, when consumers either do not care much about choosing a particular brand or do not believe that they possess the knowledge to choose the appropriate brand, they may be more likely to make brand decisions on the basis of such secondary associations as an affiliation with a cause.

\section{Which Cause to Choose?}

From a branding perspective, there are two distinct paths to choosing a cause: commonality versus complementarity. In other words, the choice of a cause revolves largely around whether to reinforce existing brand image and equity or augment and add on to that image and equity.

\section{Commonality}

The commonality strategy involves selecting a cause that shares similar associations and responses with the brand (Sen and Bhattacharya 2001). The rationale is that linking the brand with the cause will trigger consumers to enhance or bolster their existing brand associations. For example, Reebok sponsored a "Human Rights Now! Tour" with Amnesty International in 1988. Reebok believed that Amnesty International's promotion of individual rights, freedom of expression, and freedom over personal identity resonated with what the firm wanted the Reebok brand to stand for in the marketplace. Therefore, the goal of the sponsorship was to bolster existing or intended associations that consumers had about Reebok in terms of "personal expression" and "freedom."

Many people have cited the degree of affinity between the cause and company as a key component of an effective CSM program. In the brand extension literature, a key criterion used to explain the success of extensions has been the fit between a new extension product and the original brand (Broniarczyk and Alba 1994; Keller and Aaker 1992; Park, Milberg, and Lawson 1991). As with brand extensions, fit should be an important mediating factor that affects the degree of transfer to the brand of meaning about or responses toward the cause. If there is a high degree of fit, it may even appear as if the company is lending its expertise to the nonprofit (Barone, Miyazaki, and Taylor 2000). Also, as is the case with brand extensions, fit may be based on a variety of different considerations or types of associations.

$\mathrm{P}_{9}$ : Partnering with causes with a high degree of fit will enhance commonality and strengthen existing brand knowledge.

\section{Complementarity}

One limitation associated with the commonality strategy may be the level of differentiation that could be developed. By definition, if a corporate or product brand is partnered with a nonprofit cause that shares much of the same meaning and elicits similar judgments and feelings, then there is less opportunity for the creation of unique associations. If a firm is trying to create a perceived differential advantage where none currently exists, then a CSM strategy based on complementarity may be appropriate, whereby the firm attempts to augment existing brand knowledge by partnering with a nonprofit. In effect, the firm is attempting to leverage the affiliation with the nonprofit to enhance the 
meaning associated with the brand in the minds of consumers. As noted previously, CSM can be an especially useful way to create some valuable intangible imagery associations and feelings that may otherwise be difficult to create.

Examples of firms using the complementarity strategy in partnering with nonprofits are comparatively less frequent. As one example, Harley-Davidson has been a long-time supporter of the Muscular Dystrophy Association. Although this association should soften the image that HarleyDavidson has developed over the years through its relationship with the "Hells Angels," the company does not tout its support (Meyer 1999). Along these lines, one goal of the complementarity approach may be to mitigate the effects of criticism and/or problematic corporate behavior (Drumwright and Murphy 2001). Alcohol companies have spent considerable funds promoting the "safe" use of their products. For example, Anheuser-Busch (2001) comments on its Web site, "With programs under way in almost every community across the United States to fight alcohol abuse, drunk driving, and underage drinking, Anheuser-Busch and its nationwide team of independently owned wholesale distributors lead the industry in promoting alcohol awareness and education."

The complementarity approach may be the preferred method for creating sustainable differentiation if specific associations derived from the CSM program are more difficult to copy. Indeed, prior research drawing on organizational identification theory has shown that participation in similar organizations is negatively related to identification with the focal organization (Bhattacharya, Rao, and Glynn 1995). The implication from a competitive standpoint is the breath of benefits that may be derived from a CSM program. Not only are positive associations transferred to the brand, but also the probability of one of the competitors transferring similar associations at the same time is lessened (Bhattacharya, Rao, and Glynn 1995).

There are several challenges, however, in using CSM programs for brand differentiation. First, because the brand is moving into "new territory," it may lack credibility, and consumers may find it difficult to "buy into" the association. Alcohol and tobacco manufacturers have faced this problem as they partner with causes that were founded to mitigate the negative components of their respective consumption. This suspicion or lack of belief may be especially evident if the associations linked to the cause are in some sense negatively correlated with existing brand associations. Second, many popular causes already have several corporate sponsors. Reportedly, more than 300 companies currently associate themselves with breast cancer as a cause in some way. As a consequence, the brand may find itself "lost in the shuffle" and overlooked. With weak identification to the cause, the effects of the CSM program may be diluted.

Finally, as more and more firms adopt CSM approaches, the opportunities for creating perceived differential advantages should naturally lessen. Indeed, CSM programs may ultimately be necessary just to create "points of parity" with consumers to match or negate the marketing efforts of other firms. For example, $P \& G$ 's recent focus on women's issues could be interpreted in part as a means of refuting a current potential point of difference held by Avon. Similarly, BMW's support of the Susan G. Komen Breast Cancer Foundation may be perceived as an attempt to diminish the differential advantage that Ford had acquired, by supporting (and linking the BMW brand with) the same foundation.

$$
\begin{aligned}
& \mathrm{P}_{10} \text { Partnering with causes with a low degree of fit (a) can } \\
& \text { enhance differentiation and complementarity more than } \\
& \text { partnering with causes with a high degree of fit and (b) will } \\
& \text { be more difficult than partnering with causes with a high } \\
& \text { degree of fit. }
\end{aligned}
$$

\section{How Should CSM Activities Be Branded?}

There are three distinct options for branding a newly launched CSM program. First, a firm could create an entirely new cause program that is then branded in some fashion with either the corporate name or the name of one of the product brands. Second, the corporate or product brands could be linked directly with an existing cause-related organization. Third, a firm could link to an existing cause-related organization but develop a branded CSM program to link to it. Each of these three types of CSM program options is depicted subsequently and an example of each form is described, followed by an analysis of factors that affect which alternative to employ.

\section{CSM Branding Alternatives}

\section{Create Own Self-Branded Cause}

In this form of CSM program, the firm takes ownership of a cause and develops an entirely new organization to deliver benefits associated with the cause. The newly created selfbranded cause could be branded with the parent brand or an individual product brand. The Ronald McDonald House Charities and the Avon Breast Cancer Crusade are classic examples of branded cause entities:

Ronald McDonald House Charities. Ronald McDonald House Charities provides comfort and care to children and their families by supporting Ronald McDonald Houses in communities around the world and by making grants to other not-for-profit organizations whose programs help children in need. Ronald McDonald House Charities has a network of over 174 local charities serving in 32 countries. McDonald's Corporation is committed to giving something back to the community by supporting [Ronald McDonald House Charities] initiatives. (McDonald's 2001)

The Avon Breast Cancer Crusade. Founded in 1993, the Avon Breast Cancer Crusade is a U.S. initiative of Avon Products Inc. Its mission has been to provide women, particularly those who are medically underserved, with direct access to breast cancer education and early detection screening services: mammograms and clinical breast exams. In the U.S., Avon is the largest corporate supporter of the breast cancer cause, with some $\$ 100$ million generated since 1993. The Crusade raises funds to accomplish this mission in two ways: through the sale of special Crusade fundraising (pink ribbon) products by Avon's nearly 500,000 independent sales representatives and through the Avon Breast Cancer 3-days, a series of three-day, 60-mile fundraising walks. (Avon Company 2001)

\section{Cobranded: Link to Existing Cause}

In this form of CSM program, the firm would partner with an existing cause. Typically, the identification of the brand affiliation with the cause is only in the form of designation 
as a sponsor or supporter-the actual involvement is not branded as a program in any way. Currently, cobranding relationships with causes are the most popular type of CSM activity. For example, American Airlines has been a longtime supporter of the Komen Foundation:

\begin{abstract}
American Airlines and the Komen Foundation. In 1992, American Airlines, one of the world's largest air carriers, began an employee breast cancer education and awareness program in conjunction with the Komen Foundation, which included distributing shower cards and educational materials to 115,000 employees. American Airlines orchestrated a program that organized employee support groups and trained the corporate nursing staff to conduct breast health seminars throughout its system in the domestic U.S. Since that time, American Airlines has been an invaluable partner of the Komen Foundation, and in 1994 was named the "official carrier" of the Komen Foundation. In addition, American continues its support as a National Series Sponsor of the Komen Race for the Cure. American also has established the annual American Airlines Celebrity Gold Weekend. (Komen Foundation 2001)
\end{abstract}

\section{Jointly Branded: Branded Link to Existing Cause}

Finally, in this hybrid approach, firms partner with an existing cause but explicitly brand their program that links to the cause. The American Express "Charge Against Hunger" campaign was one of the more widely known and successful joint-branded relationships:

American Express and Charge Against Hunger. From 1993 to 1996, Share Our Strength and American Express united in the Charge Against Hunger campaign, the nation's most visible and successful cause-related marketing partnership. The partnership was formed with a very specific goal in mind-to raise money for and create awareness of the problem of hunger in America. The campaign's fundraising total for four years is \$21 millionone of the largest corporate contributions ever to fight hunger. For American Express, the Charge Against Hunger campaign was a total corporate commitment involving employees, Card members, and merchants. The campaign raised awareness among the general public of the hunger problem in America. (Share Our Strength 2001)

\section{How Should a Firm Decide Which Way to Go?}

Although a host of concerns may factor into the choice, two general areas should be examined in making the CSM branding decision-the initial objectives and goals of the CSM program and the resource commitment and focus that would be required to make the CSM program a success.

\section{Objectives and Goals}

A factor to take into consideration when making the CSM branding decision is the brand-building goal, such as commonality versus complementarity. If the goal were to complement existing brand equity with specific associations, then some form of cobranding or, even better, joint branding would most likely be the appropriate choice. The rationale would be, in part, that the complementarity strategy is based on the transfer of specific associations to a brand. Although it is possible that specific associations could be built up from scratch with the development of a new self-branded cause program, it is more likely that an existing nonprofit cause will have existing associations that can be more effectively and quickly transferred to the brand. Moreover, exist- ing causes may have a large number of people who already support the cause in some manner. These supporters are probably more likely to become aware of the CSM relationships and have a match between their existing values and the values associated with the cause they are already supporting. As discussed previously, increased awareness and personal relevance should enhance the transfer of associations from the nonprofit to the brand.

$\mathrm{P}_{11}$ : Cobranding through a CSM program is most appropriate as a means to complement the brand image with the specific associations leveraged from the cause.

In contrast, if the goal is to enhance the existing associations through emotional and imagery appeals, then the more effective route would be to create and self-brand a cause that is linked to the brand. Self-branding a new cause enables firms to analyze critically what aspects of salience, meaning, responses, and relationships would most improve the brand's strength. The cause could then be created to maximize those goals. With self-branding, the firm could create and position a cause to maximize both the benefits to society and brand-building effectiveness.

$\mathrm{P}_{12}$ : Self-branding a CSM program is most appropriate as a means of augmenting existing consumer associations through emotional or imagery appeals.

Last, joint branding combines elements of both of the preceding types. Joint branding a CSM program is a means of achieving the "best of both worlds" of leveraging and creating brand associations. Again, the goal of commonality or complementarity would surely guide the selection of the cause in joint branding. Although this form seems to have all the benefits of cobranding, with a stronger identity for the firm, some causes may be leery of lending their name to a private partner.

$\mathrm{P}_{13}$ : Cobranding a CSM program will lead to increased levels of both complementing existing brand images and augmenting new images.

\section{Resource Commitment and Focus}

Two keys for creating successful brand-building marketing programs are the amount and nature of marketing support involved and the focus or consistency of the marketing support. The minimum investment required for a CSM program to have an impact on brand equity will depend in part on the quality of the marketing support. That is, although adequate financial resources are important, the timing, execution, themes, and other qualitative factors will also play an important role in the ultimate success of a CSM program. With CSM, the positive impact on the brand may be lessened by sporadic involvement in several causes. For example, although Shell Oil has been a leading philanthropist in the United States through the years, it has tended to support multiple disparate nonprofit groups. Although Shell Oil has provided a high level of support for nonprofit activities, it has not gained as many of the benefits as possible because of a scattered approach that has led to little communication and consistency within the firm's CSM efforts.

In such cases, the creation of a new cause or self-branding a cause might provide greater consistency and exposure for consumers and make a stronger and more positive impression. Moreover, a self-branded cause could garner more 
resources initially within an organization. If self-branded causes are viewed as strategically important for the development of a brand, then initial resources committed to the cause should be at higher levels. In addition, from a consistency perspective, a self-branded cause is more likely to have long-term support. When the company's name is on the line, it is less likely that senior management will view support for the program as discretionary. The resource commitment for a self-branded cause may mean that the firm necessarily will need to withdraw from other CSM programs and activities, especially if it desires to achieve as much brand equity as possible. More diffuse efforts may not be able to achieve many of the six possible routes to build brand equity with CSM.

For example, one of the most successful CSM programs was American Express's "Charge Against Hunger" campaign described previously. From a branding perspective, Charge Against Hunger seemed like the ideal CSM program. Similar to the BMW Drive for the Cure program, Charge Against Hunger enabled consumers to support a cause while using the brand. Yet Charge Against Hunger was jointly branded with Share Our Strength. Every year, proponents of the Charge Against Hunger campaign fought corporate budget battles to keep the program funded, and eventually American Express just shifted its focus and support to other areas. Had the Charge Against Hunger campaign been self-branded and administered by American Express, it might not have been terminated in 1996. Note also that in doing so, American Express undoubtedly was walking away from some equity it had built up in branding the program.

\section{Conclusions}

In this article, we examine the brand equity-building implications of CSM programs. In doing so, we make several assumptions. First and foremost, we assume that CSM programs are good for society as a whole. Although we believe that this is the case, there is some scholarly debate about the overall effects of CSM programs (Andreasen and Drumwright 2001; Smith and Higgins 2000). Second, we assume that making CSM programs more effective for businesses should lead to enhanced use of CSM programs. Last, we assume that there are substantial benefits to nonprofit entities that coincide with participation with corporate partners. In the next section, we detail a research agenda toward the goal of improving the effectiveness of CSM programs.

\section{Emerging Research Areas}

Each of the research propositions (see Table 1) suggests a set of research questions to investigate. More generally, the three factors in the CSM brand hierarchy model need to be examined in terms of mediation and moderation. In particular, the role of fit deserves close scrutiny in terms of complementarity strategies. As mentioned previously, this approach appears to hold the greatest potential advantage with regard to CSM programs for firms that are trying to differentiate their brands. Yet this approach is seldom used in

Table 1. CSM Research Propositions

\section{CSM Area}

Building brand awareness

Enhancing brand image

Enhancing brand image

Evoking brand feelings

Evoking brand feelings

Relevance and meaningfulness of the cause

Relevance and meaningfulness of the cause

Transferring meaning from

the cause

Choosing a cause to support

Choosing a cause to support

Choosing CSM form

Choosing CSM form

Choosing CSM form

\section{Research Proposition}

$\mathrm{P}_{1}$ : CSM programs (a) will lead to increases in awareness for a brand and (b) will not lead to enhanced associations related to specific consumption or usage situations.

$\mathrm{P}_{2}$ : The more prominent user imagery is in the marketing program (e.g., as the focus of an advertising campaign), the more likely it is that the brand image will be enhanced.

$\mathrm{P}_{3}$ : Abstract associations are more likely to be transferred from a cause to a brand than concrete associations are.

$\mathrm{P}_{4}$ : Enhanced levels of feelings of social approval will be created when CSM programs provide consumers with external symbols to explicitly advertise or signal their affiliation to others.

$\mathrm{P}_{5}$ : Enhanced levels of feelings of self-respect will be created when CSM programs provide consumers with moments of internal reflection that reinforce the positive outcomes associated with the cause program and the way their involvement contributed to that success.

$\mathrm{P}_{6}$ : The more consumers perceive fit or similarity of the cause to the brand, the more likely consumers will infer similar associations to the brand.

$\mathrm{P}_{7}$ : Consumers will have greater levels of relevance for a brand when the CSM program partner has a higher perceived personal impact.

$\mathrm{P}_{8}$ : The more opportunities a consumer has to experience connections between the cause and the brand, the stronger will be the associations between the cause and the brand.

$\mathrm{P}_{9}$ : Partnering with causes with a high degree of fit will enhance commonality and strengthen existing brand knowledge.

$\mathrm{P}_{10}$ : Partnering with causes with a low degree of fit (a) can enhance differentiation and complementarity more than partnering with causes with a high degree of fit and (b) will be more difficult than partnering with causes with a high degree of fit.

$\mathrm{P}_{11}$ : Cobranding through a CSM program is most appropriate as a means to complement the brand image with the specific associations leveraged from the cause.

$\mathrm{P}_{12}$ : Self-branding a CSM program is most appropriate as a means of augmenting existing consumer associations through emotional or imagery appeals.

$\mathrm{P}_{13}$ : Cobranding a CSM program will lead to increased levels of both complementing existing brand images and augmenting new images. 
practice. If all the talk about the commoditization of products is believed, then perhaps differentiation through CSM programs plays an important role in the future development of brands. Relatedly, an additional area that needs to be carefully investigated is the effects of CSM programs on brand imagery and feelings, especially in terms of how they are transferred from the cause to the brand. Many brands struggle to create such knowledge among their consumers, and the ability of CSM programs to make progress in this direction would be important.

Although the research propositions highlight several CSM concerns, we could not address other CSM issues in this article. In the remainder of this section, we identify four potentially worthwhile directions for further research.

\section{Understanding the Return on Investment for CSM Programs and Alternative Branding Strategies}

There are several important research issues involved in the choice of a CSM branding strategy. How does the branding strategy affect the three factors involved in the CSM brand hierarchy model? In other words, how does the choice of a cobranded, self-branded, or jointly branded CSM program affect the kind of associations and beliefs that can become linked to the brand? For example, is it the case that selfbranded or perhaps even jointly branded programs are better able to create a sense of community and engagement with consumers but may not have as much immediate potential in terms of credibility?

Implicit in the question of choosing a CSM branding strategy is the investment required and therefore the return on investment that can be expected from a CSM program. The question is whether many of the benefits and different means by which CSM programs can affect brand equity can be realized with smaller budgets. Can small expenditures on CSM yield disproportionate financial gains or increases in brand equity? How does that depend on the branding strategy involved? The theoretical mechanisms and possible range of effects identified previously should help guide measurement efforts in tracking the impact of CSM programs.

In general, trying to quantify the effects of CSM programs can be done through traditional measurement contexts (e.g., as BMW did when trying to assess the number of new automobiles that was sold directly because of the Drive for the Cure program) and through unconventional methods. Cravens and Guilding (1999) discuss the notion of formal brand valuations as an aid to decision making for marketing managers. These brand valuations could be used to estimate the potential effects of a CSM program. In addition, the notion of capturing and measuring customer equity has been used as a vehicle to measure the effects of corporate CSM programs (Rust, Zeithaml, and Lemon 2001).

\section{Understanding How to Communicate CSM Programs}

A related issue is how the CSM program expenditures should be allocated (Biehal and Sheinin 1998). Should expenditures go primarily to the nonprofit cause itself, to promoting the firm's connection with that cause, or to various closely related matters (e.g., informing consumers of the firm's investment in the cause)? Some type of communication expenditures is necessary, regardless of the branding strategy, if nothing else to make consumers aware of the connection from the brand to the cause. Yet many firms traditionally have not publicized their involvements in charitable concerns. As this type of involvement takes on more strategic objectives, some level of communication will be needed. If CSM partners are perceived as more trustworthy, perhaps communication from the nonprofit organization will be a more effective means to publicizing the CSM relationship. Overcommunicating CSM programs, however, could lead to creation of ill will through charges of exploitation (Blazing and Bloom 1999; Webb and Mohr 1998). Some firms have been criticized for spending more money advertising their cause programs than supporting the cause itself.

It would be helpful if firms had a better understanding of the key drivers of appropriateness from a consumer perspective. Along those lines, understanding the effects of different communication objectives-focusing on the cause itself, the money being given to the cause by the firm, the money being raised (from other sources) for the cause, or the connection between the firm and the cause-is crucial.

\section{Understanding CSM Programs and Lasting Competitive Advantages}

One critical question is, Can CSM programs create sustainable competitive advantages for firms? Some insight might be gleaned from examining the pioneering advantage literature. Although many scholars have debated the existence of a pioneering advantage for new product introductions, a critical distinction arose surrounding the definition of a pioneer. It appears that being first was simply not enough. To gain a "pioneering advantage," firms needed to have massive trial in the marketplace (Golder and Tellis 1993). Analogously, for firms to truly gain lasting brand-based advantages through CSM relationships, they may need massive corporate commitment and considerable consumer awareness. For example, was Ford able to maintain some advantage by supporting the Komen Foundation first?

A related long-term issue of CSM programs is, Once a firm publicly proclaims its commitment to a cause, can it ever "win" if the problems to be remedied by the cause are never solved? How much progress must be made before there is brand equity impact? Will there inevitably be a loss of image or tarnished reputation if the firm drops the cause or switches to another cause? What is an appropriate "exit strategy" from a cause? All these issues may depend on the nature of the branding strategy adopted and which of the six means to build brand equity are involved with the cause program.

\section{Understanding the Impact on Nonprofits}

From the perspective of the causes or nonprofit organizations themselves, there seem to be mostly benefits to becoming part of a CSM marketing program with a firm. Moreover, even if firms begin to move more in the direction of self-branding causes, the resulting heightened awareness of the cause could lead to increased levels of support. Cobranding with corporate sponsors, however, offers several advan- 
tages for nonprofits. First and foremost, corporations can provide much-needed resources in both funds and expertise. Although funding is rather straightforward, business skills may be equally valuable to some nonprofits. For example, one of the key skills that many firms are attempting to enhance is customer relationship management. These skills will be of value to existing nonprofits. Second, partnering with firms may enable nonprofits to increase the affiliation and level of engagement they have with supporters. This could happen through increased awareness and through programs such as strategic volunteerism, as noted previously.

\section{References}

Aaker, David A. and Erich Joachimsthaler (2000), Brand Leadership. New York: The Free Press.

Aaker, Jennifer L. (1997), "Dimensions of Brand Personality," Journal of Marketing Research, 34 (August), 347-57.

(1999), "The Malleable Self: The Role of Self-Expression in Persuasion," Journal of Marketing Research, 36 (February), 45-57.

Andreasen, Alan R. and Minette E. Drumwright (2001) "Alliances and Ethics in Social Marketing," in Ethical Issues in Social Marketing, Alan K. Andreasen, ed. Washington, DC: Georgetown University Press, 95-124.

Anheuser-Busch Publications (2001), Making Friends-Making A Difference (accessed December 13), [available at http:// www.anheuser-busch.com/publications/default.htm].

Avon Company (2001), Avon Breast Cancer Crusade (accessed December 13), [available at http://www.avoncompany.com/ women/avoncrusade/].

Barich, Howard and Philip Kotler (1991), “A Framework for Marketing Image Management,” Sloan Management Review, 32 (2), 94-104.

Barone, Michael J., Anthony D. Miyazaki, and Kimberly A. Taylor (2000), "The Influence of Cause-Related Marketing on Consumer Choice: Does One Good Turn Deserve Another?" Journal of the Academy of Marketing Science, 28 (2), 248-62.

Bhattacharya, C.B., Hayagreeva Rao, and Mary Ann Glynn (1995), "Understanding the Bond of Identification: An Investigation of Its Correlates Among Art Museum Members," Journal of Marketing, 59 (October), 46-57.

Biehal, Gabriel J. and Daniel A. Sheinin (1998), "Managing the Brand in a Corporate Advertising Environment: A DecisionMaking Framework for Brand Managers," Journal of Advertising, 27 (2), 99-110.

Blazing, Jennifer and Paul N. Bloom (1999), "How Perceptions About the Purity of Sponsor Motives Affect the Persuasiveness of Socially-Oriented Communications," working paper, Department of Marketing, University of North Carolina at Chapel Hill.

Broniarczyk, Susan M. and Joseph W. Alba (1994), "The Importance of the Brand in Brand Extension," Journal of Marketing Research, 31 (May), 214-28.

Brown, Tom J. (1998), "Corporate Associations in Marketing: Antecedents and Consequences," Corporate Reputation Review, 1 (3), 215-33.

- and Peter A. Dacin (1997), "The Company and the Product: Corporate Associations and Consumer Product Responses," Journal of Marketing, 61 (January), 68-84.
Cone Inc. (1999), Cone/Roper Cause-Related Trends Report. Boston: Cone Inc.

Cravens, Karen S. and Chris Guilding (1999), "Strategic Brand Valuation: A Cross-Functional Perspective," Business Horizons, 42 (4), 53-62.

Dawar, Niraj and Madan M. Pillutla (2000), "Impact of ProductHarm Crises on Brand Equity: The Moderating Role of Consumer Expectations," Journal of Marketing Research, 37 (May), 215-26.

Drumwright, Minette (1996), "Company Advertising with a Social Dimension: the Role of Noneconomic Criteria," Journal of Marketing, 60 (October), 71-87.

— and Patrick E. Murphy (2001), "Corporate Societal Marketing," in Handbook of Marketing and Society, Paul N. Bloom and Gregory T. Gundlach, eds. Thousand Oaks, CA: Sage Publications, 162-83.

Farquhar, Peter H. (1989), "Managing Brand Equity," Marketing Research, 1 (September), 24-33.

File, Karen Mary and Russ Alan Prince (1998), "Cause Related Marketing and Corporate Philanthropy in the Privately Held Enterprise," Journal of Business Ethics, 17, 1529-39.

Fournier, Susan (1998), "Consumers and Their Brands: Developing Relationship Theory in Consumer Research," Journal of Consumer Research, 24 (3), 343-73.

Golder, Peter N. and Gerard J. Tellis (1993) "Pioneer Advantage: Marketing Logic or Marketing Legend?" Journal of Marketing Research, 30 (February), 158-70.

Graeff, Timothy R. (1996), "Image Congruence Effects on Product Evaluations: The Role of Self-Monitoring and Public/Private Consumption," Psychology \& Marketing, 13 (5), 481-99.

Habitat for Humanity International (2001), Corporate Partners (accessed December 13), [available at http://www.habitat.org/ $\mathrm{CP} /$ featured.html].

Johnson, Michael D. (1984), "Consumer Choice Strategies for Comparing Noncomparable Alternatives," Journal of Consumer Research, 11 (December), 741-53.

Kahle, Lynn R., Basil Poulos, and Ajay Sukhdial (1988), "Changes in Social Values in the United States During the Past Decade," Journal of Advertising Research, 28 (February/March), 35-41.

Keller, Kevin Lane (1993), "Conceptualizing, Measuring, and Managing Customer-Based Brand Equity," Journal of Marketing, 57 (January), 1-22.

(1998), Strategic Brand Management. Upper Saddle River, NJ: Prentice Hall.

(2001), "Building Customer-Based Brand Equity: A Blueprint for Creating Strong Brands," Marketing Management, 10 (July/August), 15-19.

— and David A. Aaker (1992), "The Effects of Sequential Introduction of Brand Extensions," Journal of Marketing Research, 29 (February), 35-50.

Komen Foundation (2001), Our Sponsors (accessed December 13), [available at http://www.komen.org/sponsors/ american_airlines.asp].

Lichtenstein, Donald R., Minette E. Drumwright, and Bridgette M. Braig (2000), "Perceptions of Corporate Giving on CustomerCorporation Identification: Beneficial Effects for Customer, Corporation, and Nonprofit," working paper, College of Business Administration, University of Colorado, Boulder. 
McDonald's Corporation (2001), Corporate: Social Responsibility RMHC (accessed December 13), [available at http:// www.mcdonalds.com/corporate/social/rmhc/index.html].

Menon, Ajay and Anil Menon (1997), "Enviropreneurial Marketing Strategy: The Emergence of Corporate Environmentalism as Market Strategy," Journal of Marketing, 61 (January), 51-67.

Meyer, Harvey (1999), "When the Cause Is Just," Journal of Business Strategy, 20 (November/December), 27-31.

Muniz, Albert M., Jr., and Thomas C. O’Guinn (2000), "Brand Community," Journal of Consumer Research, 27 (March), 412-32.

Muscular Dystrophy Association (2001), Ways to Help MDA: SponsorShip (accessed December 13), [available at http:// www.mdausa.org/help/sponsor.html].

Park, C. Whan, Sandra Milberg, and Robert Lawson (1991), "Evaluation of Brand Extensions: The Role of Product Feature Similarity and Brand Concept Consistency," Journal of Consumer Research, 18 (September), 185-93.

Pringle, Hamish and Marjorie Thompson (1999), Brand Spirit. West Sussex, England: John Wiley \& Sons.

Rust, Roland, Valarie Zeithaml, and Katherine Lemon (2001), "Quantifying the Impact of Corporate Ethics on Customer Equity," presentation at Marketing Science Institute Conference: Marketing, Corporate Social Initiatives and the Bottom Line, Chapel Hill, NC (March 14-16).

Schumann, David W., Jan M. Hathcote, and Susan West (1991), "Corporate Advertising in America: A Review of Published
Studies on Use, Measurement, and Effectiveness," Journal of Advertising, 20 (September), 36-56.

Sen, Sankar and C.B. Bhattacharya (2001), "Does Doing Good Always Lead to Doing Better? Consumer Reactions to Corporate Social Responsibility," Journal of Marketing Research, 38 (May), 225-43.

Share Our Strength (2001), Charge Against Hunger (accessed December 13), [available at http://www.strength.org/meet/ partnerships/charge/charge.htm].

Smith, Warren and Matthew Higgins (2000), "Cause-Related Marketing: Ethics and Ecstatic," Business and Society, 39 (3), 304-22.

Stark, Myra (1999), "Brand Aid: Cause Effective," Brandweek, 40 (February 22), 20-22.

Varadarajan, P. Rajan and Anil Menon (1988), "Cause-Related Marketing: A Coalignment of Marketing Strategy and Corporate Philanthropy," Journal of Marketing, 52 (July), 58-74.

Webb, Deborah J. and Lois A. Mohr (1998), “A Typology of Consumer Responses to Cause-Related Marketing: From Skeptics to Socially Concerned," Journal of Public Policy \& Marketing, 17 (2), 226-38.

Zaltman, Gerald and Robin Higie (1995), "Seeing the Voice of the Customer: The Zaltman Metaphor Elicitation Technique," Marketing Science Institute Report Number 93-114. Cambridge, MA: Marketing Science Institute. 
Copyright $\odot 2003$ EBSCO Publishing 